\title{
Formel og funktionel grammatik
}

\section{OLE TOGEBY}

\begin{abstract}
I denne artikel sammenlignes formelle, generative grammatikeres med funktionelle grammatikeres behandling af forholdet mellem form og mening på sprogets forskellige niveauer: lyd og grafer, morfemer og ord, sætninger, ytring af tekster og sproglige handlinger. Beskrivelsesapparatet for ledsætningsordstilling på dansk hos de generative grammatikere Platzack, Hrafnbjargarson, og Ken Christensen, og hos de funktionelle grammatikere Diderichsen, Hansen og Heltoft, og Togeby diskuteres, og det konstateres at metasproget og notationssystemerne på trods af store forskelle ikke er uforenelige, men at notationssystemerne i den formelle grammatik bedst sikrer konsistens og modsigelsesfrihed. Metoderne for falsifikation af teorierne sammenlignes, og det konstateres at den funktionelle metode giver mulighed for mere raffinerede falsifikationsprocedurer end den generative grammatiks acceptabilitetstests. Som erkendelsesinteresse har den generative grammatik først og fremmest at finde den universelle grammatik som angiveligt udgør det biologiske grundlag (generativitet og rekursivitet) for sprogudøvelsen, mens den funktionelle grammatik søger at finde hvad der i evolutionen og historien har adskilt mennesket fra menneskeaberne, nemlig sprog der hviler på socialitet, tillid og kultur. Til sidst vises det hvorledes erkendelsesinteressen i hhv. biologi og socialitet har givet forskellige resultater i beskrivelsen af konstruktionsændringen fra Det fortryder mig til Jeg fortryder det på dansk. Det konkluderes at de to lingvistiske skoler med fordel kan arbejde sammen om beskrivelser i detaljen.
\end{abstract}

EMNEORD: grammatik, generativ grammatik, funktionel grammatik, grammatisk notation

\section{SPROGETS NIVEAUER}

Der er i Danmark to dominerende paradigmer for beskrivelse af sproglig grammatik: det generative paradigme og det funktionelle paradigme. Den umiddelbare forskel ligger i om man beskriver en sproglig tekst generativt nedefra og op, dvs. hvorledes rækkefølgen af de mindste formelementer 
genereres så de udtrykker den samlede mening, eller funktionelt oppefra og ned, dvs. hvorledes et overordnet formål realiseres i rækkefølgen af ytrede formelementer i en konkret tekst. Når folk bruger sprog til at dele tanker med hinanden, sker det givetvis begge veje samtidig i det der er blevet kaldt den hermeneutiske cirkel. I denne artikel skal det undersøges hvilke fordele og ulemper der er ved de to beskrivelsesmåder.

Det at forbinde former og mening (enten oppefra og ned eller nedefra og op) involverer som vist i figur 1 for sprogbrugerne en række lag og dertil knyttede indlærte regelsystemer: lydlaget med sproglyd og bogstaver som alene har adskillende funktion; ordlaget med leksikalske morfemer der har konceptuel mening; syntakslaget med grammatiske morfemer og ordstilling i sætninger som har propositionel eller logisk mening; tekstlaget hvor flere sætninger er sat sammen til en helhed med nogle informationer i baggrunden og et informationelt fokuseret budskab i forgrunden, og handlingslaget med sociale handlinger og formål. Lagene svarer til de underdiscipliner som har udviklet sig i sprogvidenskaben: fonetik, leksikalsk semantik, morfologi, syntaks og logik, tekstlingvistik med relevansteori, og pragmatik med talehandlingslære.

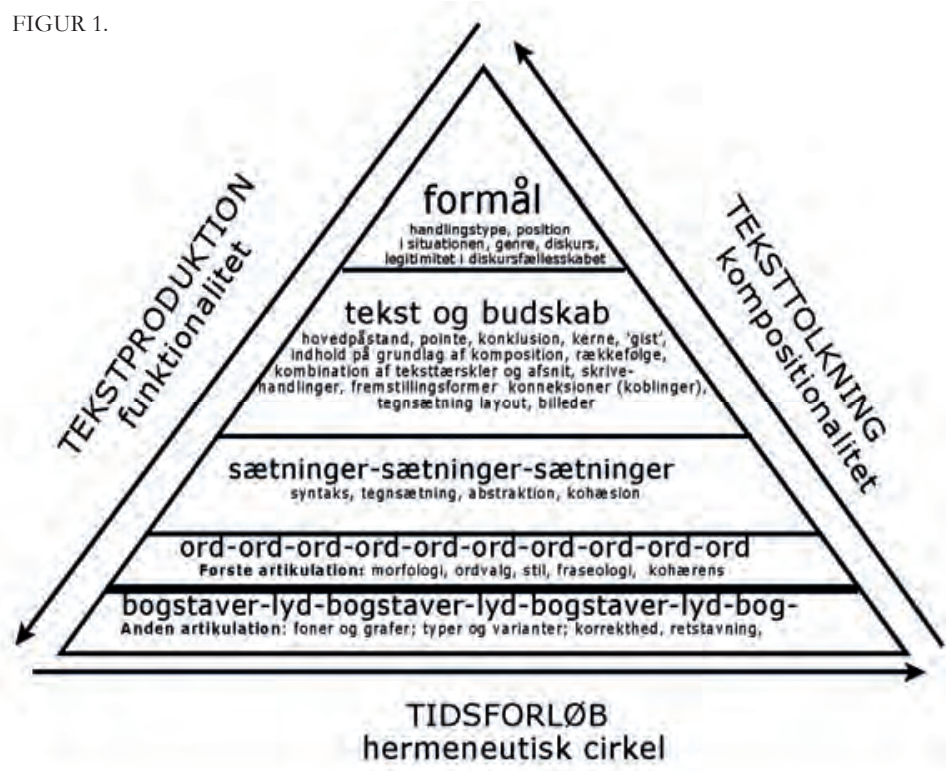


De to grammatiske skoler har vidt forskellige betegnelser for niveauerne: Generativisterne kalder således lagene over lyd- og bogstavlaget for hhv. VP (Verb Phrase), IP (Inflectional Phrase) og CP (Complementiser Phrase) eller hhv. Thematic Form, Grammatical Form og Discourse Form (Platzack 1998), mens funktionalisterne kalder dem for experiential metafunction, logical metafunction, textual metafunction, interpersonal metafunction (Halliday 1994) eller state of affairs, possible fact, speech act (Dik 1989).

Det er ikke helt klart i hvor høj grad parterne mener det samme med deres forskellige betegnelser, men de identificerer de samme niveauer i en sproglig ytring, selv om de anskuer dem fra forskellige synsvinkler og opfatter dem forskelligt. Det er disse forskelle denne artikel handler om.

Det er påfaldende at de formelle grammatikere opfatter niveauerne som niveauer af former, mens funktionalisterne opfatter dem som niveauer af funktion eller mening. Det ser ud som om to parter vil bore en tunnel gennem et bjerg ved at begynde fra hver sin side, og man kan så håbe på at de mødes på midten. Niveauerne er naturligvis niveauer af form $i \mathrm{og}$ med at ord er dele af sætninger, som er dele af tekster, som er dele af handlinger. Men niveauerne er også niveauer af funktion eller mening, og de kan kaldes hhv. konceptuel mening om sagforhold i den fremstillede situation, propositionel mening der har sandhedsværdi som udsagn om verden, informationel mening om budskabets relevans for teksttolkerne og interaktionel mening om hvilken handling ytringen skal tælle som.

Alle fire typer af mening er aspekter af den mening som sprogbrugerne tillægger de sproglige former i vellykket kommunikation. Det kan illustreres ved følgende diagram hvor konceptuel mening og propositionel mening efter Watzlawick (1968) beskrives som information om indholdet, dvs. om den fremstillede situation, mens informationel mening og interaktionel mening er information om relationerne $i$ den retoriske situation: 


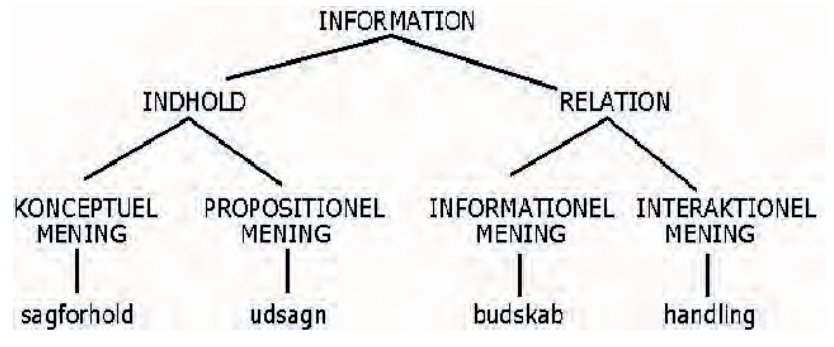

Det væsentlige i denne sammenhæng er, som fremstillet i Togeby (2003), at den ene type mening er af logisk højere orden end den anden og dermed metakommunikation i forhold til den anden, som i en løgmodel.

FIGUR 3.

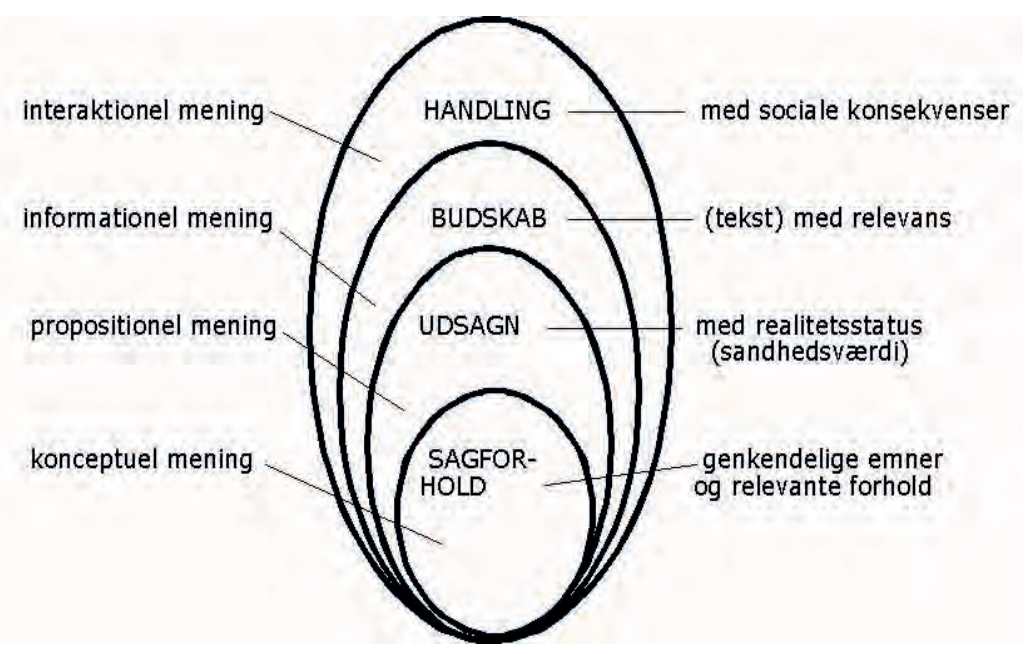

Konklusionen er at det netop er tegnrelationen der konstituerer de fire niveauer, og at der derfor på alle fire niveauer er både form og funktion, for det er forbindelsen mellem dem der konstituerer det sproglige tegn som et tegn. Men skolerne adskiller sig fra hinanden ved hvorledes de beskriver de fire niveauer og især relationerne mellem de fire niveauer. 


\section{BESKRIVELSESAPPARATET - NOTATIONEN}

En umiddelbart iøjnefaldende forskel på de to skoler er beskrivelsesapparatet, dvs. terminologien, metasproget, notationssystemerne og de metaforer der bliver brugt. Her skal der gives eksempler på notationssystemerne for ledsætningsordstilling i eksempler hentet fra nordiske funktionalister og generativister.

\section{Diderichsen}

Diderichsen beskriver forskellen på bisætninger og hovedsætninger dels ved hjælp af parentesnotation, og dels ved sætningsskemaer. Parentesnotationen angiver den hierarkisk struktur af de umiddelbare bestanddele, og skemaerne angiver ordstillingen, topologien (Diderichsen 1957: 186).

FIGUR 4.

k

Bisætningsskema:

$\mathrm{k}(\mathrm{a}(\mathrm{s} a \mathrm{v}(\mathrm{V} \mathrm{S} A)))$

s

\begin{tabular}{|l|l|l|l|l|l|l|l|}
\hline $\begin{array}{l}\text { Forbinder- } \\
\text { felt }\end{array}$ & \multicolumn{2}{|l|}{ Neksusfelt } & \multicolumn{4}{l|}{ Indholdsfelt } \\
\hline $\begin{array}{l}\text { under- } \\
\text { ordn. konj }\end{array}$ & subj. & $\begin{array}{l}\text { neksus- } \\
\text { adv. }\end{array}$ & finit & $\begin{array}{l}\text { hjælpe- } \\
\text { infinit }\end{array}$ & $\begin{array}{l}\text { fuld- } \\
\text { infinit }\end{array}$ & $\begin{array}{l}\text { obj 1-2, } \\
\text { præd }\end{array}$ & $\begin{array}{l}\text { indholds- } \\
\text { adv. }\end{array}$ \\
\hline at & han & $\begin{array}{l}\text { sikkert } \\
\text { ikeke } \\
\text { alligevel }\end{array}$ & kunne & fa & sagt & $\begin{array}{l}\text { bende } \\
\text { besked }\end{array}$ & i tide \\
\hline bvem & der & ellers & ville & & komme & & \\
\hline
\end{tabular}


Hovedsætningsskema: k ( (v s a (V S A)))

A

\begin{tabular}{|l|l|l|l|l|l|l|l|l|}
\hline $\begin{array}{l}\text { Forbin- } \\
\text { der-felt }\end{array}$ & $\begin{array}{l}\text { Fund. } \\
\text { felt }\end{array}$ & \multicolumn{4}{|l|}{ Neksusfelt } & \multicolumn{4}{l|}{ Indholdsfelt } \\
\hline konj. & $\begin{array}{l}\text { funda- } \\
\text { ment }\end{array}$ & finit & $\begin{array}{l}\text { sub- } \\
\text { jekt }\end{array}$ & $\begin{array}{l}\text { nek- } \\
\text { susadv. }\end{array}$ & $\begin{array}{l}\text { hjælpe- } \\
\text { infinit }\end{array}$ & $\begin{array}{l}\text { fuld- } \\
\text { infinit }\end{array}$ & obj. 1-2 & $\begin{array}{l}\text { indholds- } \\
\text { adv. }\end{array}$ \\
\hline og & så & kunne & han & $\begin{array}{l}\text { sikkert } \\
\text { ikke } \\
\text { alligevel }\end{array}$ & få & sagt & $\begin{array}{l}\text { hende } \\
\text { besked }\end{array}$ & i tide \\
\hline og & han & kunne & & så ikke & få & sagt & det & i tide \\
\hline
\end{tabular}

For skemaerne gælder at der kan være tomme pladser fordi et materiale ikke kan stå på en plads der er reserveret til materiale af anden kategori; skemaet angiver således stadig den indbyrdes rækkefølge af de led der faktisk er til stede i sætningen, og at de led de tomme pladser er reserveret til, enten slet ikke er udtrykt, eller står på et andet sted. Fx står subjektet han i sætningen og han kunne så ikkee få sagt det i tide på fundamentpladsen, selv om der i skemaet er reserveret subjektpladsen til det i neksusfeltet. Derved markerer ordstillingen den funktion eller mening som ordet har udover at være subjekt for det finitte verbum. Efter Diderichsen er der flere muligheder: at han er det sætningen er om, at han anaforisk genoptager noget fra det foregående, eller at han er emfatisk (Diderichsen 1957: 192). Af disse tre muligheder er det nok (vi har jo ikke sammenhængen) den anden funktion der er signaleret med ordstillingen i dette eksempel. Subjektet er ikke placeret i neksusfeltet (hvor det grammatiske subjekt hører hjemme), men i fundamentfeltet hvor det viser den tekstuelle funktion at genoptage noget fra det foregående.

\section{Hrafnbjargarson}

Den generative grammatik bruger frasestrukturtræer og flytninger af elementer fra en gren til en anden, som det kan ses på dette eksempel fra Hrafnbjargarson (2004: 24). Det er en analyse af den islandske sætning 
Ken hefur ekkei blustað â pennan geisladisk. 'Ken har ikke lyttet til denne CD'.

FIGUR 5

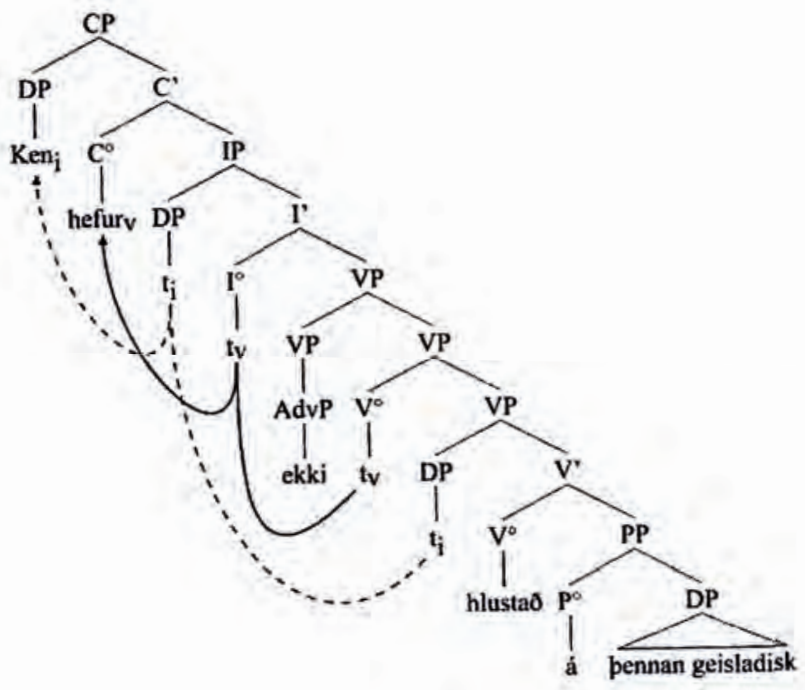

Frasestrukturanalyse af Ken hefur ekki blustað âpennan geisladisk.

Dette er en frasestrukturnotation med træer med knuder der deler sig, således at grafen både angiver rækkefølgen af ordene og konstituentstrukturen, dvs. hierarkiet af meningen med de umiddelbare bestanddele. Denne syntaktiske struktur følger (i modsætning til parentesnotationen) også det princip at knuder kun må dele sig i to (og ikke i tre eller fire), og at den leksikalske størrelse $\mathrm{X}^{\circ}$ indgår i en struktur med et komplement (søsterknuden ZP), en projektion (moderknuden X', som er den der hedder X-bar), en specifikator (mosterknuden YP) og en maksimalprojektion (bedstemoderknuden XP) (Platzack 1998: 41ff). 
FIGUR 6 .

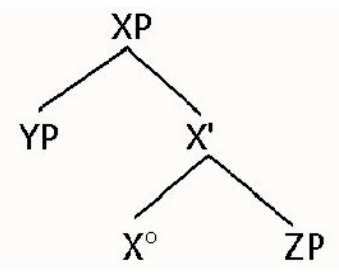

Om dette er en egenskab ved alle sprog eller en egenskab ved notationen, er ikke helt til at sige. Generativisterne påstår selv det første, dvs. at alle frasestrukturer er X-bar-strukturer, som vist i figur 6, men notationen er en forudsætning for at generativisterne kan formulere en vigtig regel om flytning, der kaldes C-command, og som omtales nedenfor. Spørgsmålet er nu: Afspejler X-bar-systemet en egenskab ved sproget, eller er det kun C-command der gør det? Med andre ord: Kunne man formulere C-command uden X-bar-systemet? Og findes der ikke tredelte strukturer i sproget, eller skal tredelte strukturer blot noteres ved træer der er todelte?

Flytningerne angiver, som de tomme pladser i Diderichsens sætningsskema, at ordene ikke står hvor de skulle i den hierarkiske struktur, og at deres faktiske placering angiver yderligere meningselementer. Når subjektet Ken ikke står på sin strukturelle plads (som $t_{j} \mathrm{i} \mathrm{VP}$ ), skyldes det at det ikke blot er semantisk argument for prædikatet i VP, men også som grammatisk subjekt danner sætning (neksusforbindelse) sammen med det tidsbøjede verbum (som t;) i IP, og desuden udgør ytringens fokus i CP. Flytningerne (som i diagrammet er angivet ved røvballegardinpilene) angiver således meningen med ordstillingen - forudsat at vi kender reglerne for tegningen af grafer, og forudsat at alle sætninger har den angivne struktur. Pointen er at ordstillingen angiver at Ken ikke blot har konceptuel mening men også propositionel og informationel mening. Sådanne diagrammer angiver altså både ordstilling og funktionen eller meningen med denne ordstilling.

Man kan nu bemærke at sætningens struktur er højere end sætningens form er lang. Diagrammet viser altså at ordenes indbyrdes placering angiver hvilken betydning sætningen har på både konceptuelt (VP), propositionelt (IP) og informationelt (CP) niveau, at meningen ikke 
blot fremkommer som summen af meningen med delene, men også som meningen med måden de er kombineret på. De generative træer med røvballegardiner forudsætter princippet om kompositionalitet. Den dekreterede struktur (CP-IP-VP) er således en teoretisk påstand om meningsniveauer. Denne teoretiske model tillader så formulering af meget generelle lovmæssigheder i sproget, som fx C-command som bruges til at beskrive hvilke flytninger af leksikalske størrelser der overhovedet kan forekomme, nemlig kun nedefra og op og kun til en plads der er mosterknude til en formoderknude i træet. Denne abstrakte regel hævdes så at gælde generelt for alle sprog.

\section{Ken Christensen}

Formalismerne i Chomskys generative grammatik har ændret sig gennem tiden, hvad pladsen dog ikke tillader en dokumentation af, men for øjeblikket er state of the art som fremstillet af Ken Ramshøj Christensen (2009) i følgende diagram.

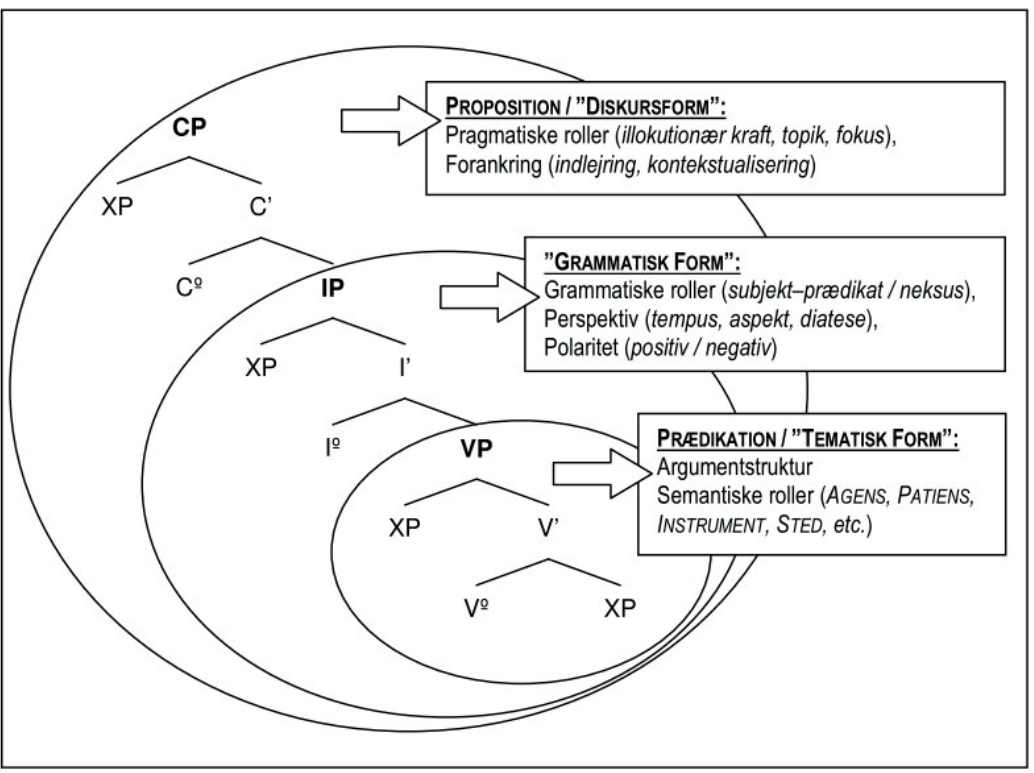

Figur 7: De tre syntaktiske domæner, CP, IP og VP, og deres betydning eller funktion. Det faktum at den samme konstituent $x$ kan være AGENS i VP, Subjekt i IP og Topik eller Fokus i CP, er det der redegøres for med begrebet "flytning". Konstituenten $x$ udtales i spec-CP, mens pladserne associeret med rollen som subjekt, spec-IP, rollen som Agens, spec-VP, er udfyldt af fonologisk "tomme", abstrakte elementer der er forbundet med $x$ i spec-CP. De tre positioner (de tre tilfælde af XP i figuren) indgår i en såkaldt kæde, hvor $x$ er antecedent og de andre spor, og hvor de tre elementer deler samme reference. 
Trædiagrammet med lagene pragmatisk CP, grammatisk IP og semantisk VP viser ikke blot niveauer i en formel struktur som kan genereres af en genskrivningsgrammatik, men typer af mening, sådan som det også er fremstillet i Togebys løgmodel (hvor der dog også skelnes mellem det informationelle og det interaktionelle lag $\mathrm{i}$ toppen).

Man kan således hævde at notationsformalismerne og graferne $i$ både den generative og den funktionelle grammatik har til formål at gøre rede for hvorledes ordenes rækkefølge angiver forskellige lag af meningen med en ytret sætning bestemt ved samspillet mellem deres strukturelle plads i hierarkiet og ordstillingen. Det er også blevet påvist overbevisende af Bjerre et al. (2008: 146) at de to typer af grammatik er ækvivalente på dette område:

FIGUR 8

b.

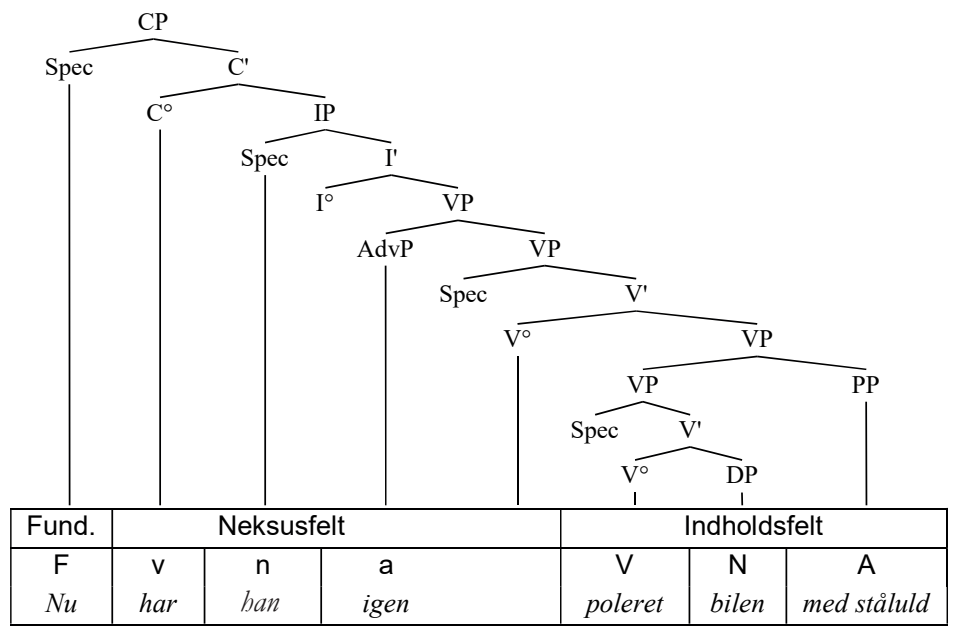

\begin{tabular}{|c|c|c|c|c|c|c|c|}
\hline \multicolumn{2}{|c|}{ Konj. felt } & \multicolumn{3}{c|}{ Neksusfelt } & \multicolumn{3}{c|}{ Indholdsfelt } \\
\hline$(\mathrm{F})$ & $\mathrm{k}$ & $\mathrm{n}$ & $\mathrm{a}$ & $\mathrm{v}$ & $\mathrm{V}$ & $\mathrm{N}$ & $\mathrm{A}$ \\
& om & han & igen & har & poleret & bilen & med ståluld \\
\hline
\end{tabular}


Man ser at både helsætningen $N u$ bar han igen poleret bilen med staluld og ledsætningen om han igen harpoleret bilen med ståluld analyseres både strukturelt og topologisk af begge grammatikker. Der er forskel på hvilken status de to grafer tildeler verbet har, i begge sætningsskemaerne er har finit verbum i neksusfeltet, men i trædiagrammet er ledsætningens har finit verbum i VP, mens har i helsætningen er finit verbum i CP, dvs. at det har fået tillagt både grammatisk og pragmatisk mening - hvad ledsætningens har ikke har. Skemaerne viser ikke denne betydningsforskel fordi man så at sige skal vide det inden man "sætter sætningen i sætningsskema", man skal nemlig vide om det er en helsætning eller en ledsætning man analyserer. Det skal også bemærkes at $\mathrm{C}^{\circ}$ i CP i helsætningen udfyldes med har, men i ledsætningen med om. Denne plads i den hierarkiske struktur er således ikke reserveret et bestemt materiale, men den syntaktiske funktion at markere pragmatiske forhold.

\section{Hansen og Heltoft}

Funktionalisterne Hansen og Heltoft (2011: 319f) anvender både dependenstræer og sætningsskemaer, og de opretholder i topologien to skemaer, det neutrale skema og det deklarative skema med et ekstra fundamentfelt, men har revideret dem i forhold til Diderichsen på en måde som svarer til den generative grammatiks trædiagrammer.

FIGUR 9. DET NEUTRALE SKEMA

\begin{tabular}{|c|c|c|c|c|c|c|c|c|}
\hline \multicolumn{8}{|c|}{ Kernefelt } & \multirow{3}{*}{\begin{tabular}{|l|}
$\begin{array}{l}\text { Lokalise } \\
\text { ringsfelt }\end{array}$ \\
FV/FA \\
\end{tabular}} \\
\hline $\mathbf{M}$ & & subjekt & \multicolumn{5}{|c|}{ Indholdsfelt } & \\
\hline $\mathbf{K}$ & $\mathrm{S}$ & SA & Vf & Vi ... & DO & $\mathbf{P}$ & MV & \\
\hline $\begin{array}{l}\text { bvis } \\
\text { mon }\end{array}$ & $\begin{array}{l}\text { de } \\
\text { brevene }\end{array}$ & $\begin{array}{l}\text { forst } \\
\text { så }\end{array}$ & $\begin{array}{l}\text { har } \\
\text { er }\end{array}$ & $\begin{array}{l}\text { sendt } \\
\text { blevet } \\
\text { destruer }\end{array}$ & $\operatorname{det}$ & ud & & igår \\
\hline$a t$ & $\operatorname{det}$ & ikkee & var & & rigtigt & & af bende & dengang \\
\hline
\end{tabular}




\begin{tabular}{|c|c|c|c|c|c|c|c|c|}
\hline \multicolumn{2}{|c|}{ Modalfelt } & \multicolumn{6}{|c|}{ Kernefelt } & \multirow{3}{*}{$\begin{array}{l}\begin{array}{l}\text { Lokalise- } \\
\text { ringsfelt }\end{array} \\
\text { FV/FA }\end{array}$} \\
\hline $\mathbf{F}$ & $\mathbf{M}$ & \multicolumn{2}{|c|}{ subjekt } & \multicolumn{4}{|c|}{ Indholdsfelt } & \\
\hline $\mathbf{X}$ & Vf & $S$ & SA & $\overline{V i}$ & DO & $\mathbf{P}$ & MV & \\
\hline$D e$ & $\begin{array}{l}\text { vil } \\
\text { Blev }\end{array}$ & bun & $\begin{array}{l}\text { nok } \\
\text { bidt }\end{array}$ & & & & $i$ benet? & straks \\
\hline $\begin{array}{l}\text { Det } \\
\text { at arbejde }\end{array}$ & $\begin{array}{l}\text { bar } \\
\text { gider }\end{array}$ & $\begin{array}{l}\text { bun } \\
\text { ban }\end{array}$ & $\begin{array}{l}\text { ikkee } \\
\text { ikkee }\end{array}$ & syet & & & & selv \\
\hline
\end{tabular}

Forkortelser: $D O=$ direkte objekt, $F=$ fundamentfelt, $F A=$ frit adverbial, $F V=$ frit valensled, $K=$ konjunktion, $M=$ modalplads, $M V=$ middelbart valensled, $S=$ subjekt, $S A=$ satningsadverbial, $V f=$ finit verbal, $V i=$ infinit verbum, $P=$ predikativ, $X$ enbver type led.

Som i trædiagrammet kan pladsen til venstre for subjektspladsen ( $M$ svarende til $\mathrm{C}^{\circ}$ i $\mathrm{CP}$ ) udfyldes af det finitte verbum i det deklarative skema og af underordningskonjunktioner i det neutrale skema. Pointen er den samme: Verbets placering angiver dets funktion som deklareret propositionel modalitet eller blot som konceptuelt indhold, og både finitte verber og konjunktioner kan have modal funktion. Som heuristisk eller pædagogisk instrument er der dog det problem at man skal vide hvilket skema man skal bruge, før man begynder analysen; man kan ikke bruge skemaet til at finde ud af hvad leddene $i$ en given sætning betyder - hvad man med lidt god vilje kan med trædiagrammet.

Hansen og Heltoft anvender også dependenstræer (som ser helt anderledes ud end frasestrukturtræer) og beskriver lovmæssigheder knyttet til prædikaternes orientering og koefficiens, men om disse forskellige lag $\mathrm{i}$ beskrivelsen altid er modsigelsesfrie kan man ikke være sikker på, for der laves ingen generaliseringer der svarer til den generative grammatiks c-kommando.

\section{Togeby}

Togeby (2003) opretholder Diderichsens funktionalistiske inddeling i tre felter under betegnelserne: konceptuelt omsagnsfelt, propositionelt udsigelsesfelt og tekstuelt fundamentfelt, men således at der kun anvendes et skema til både helsætninger og ledsætninger (Togeby 2003: $97 \mathrm{ff}$ ). 
FIGUR 11

\section{$\mathbf{F}\|\mathbf{v}-[\mathrm{k} \backslash-\mathrm{s}]-/ \mathrm{y}\|[\mathrm{a} \backslash-\mathrm{V}] \mathbf{R}-\mathbf{M} \| \mathbf{A}$}

\begin{tabular}{|c|c|c|c|c|c|c|c|c|c|c|}
\hline \multirow{2}{*}{$\begin{array}{l}\begin{array}{l}\text { Funda- } \\
\text { mentfelt }\end{array} \\
\text { F }\end{array}$} & \multirow{2}{*}{$\mathbf{v}$} & \multicolumn{2}{|c|}{ Udsigelsesfelt } & \multirow{2}{*}{$/ y$} & \multirow[b]{2}{*}{$a \backslash$} & \multirow[b]{2}{*}{$\mathbf{V}$} & \multicolumn{3}{|c|}{ Omsagnsfelt } & \multirow{2}{*}{$\begin{array}{l}\text { Uds.- } \\
\text { adv. } \\
\text { A }\end{array}$} \\
\hline & & $\mathbf{k} \backslash$ & $\mathrm{s}$ & & & & $\mathbf{R} 1$ & $\mathbf{M}$ & $\mathbf{R} 2$ & \\
\hline \multirow[t]{2}{*}{ bun } & sov & & & altid & & & & & & \\
\hline & & fordi & bun & & altid & sov & & & & \\
\hline \multirow[t]{2}{*}{ ham } & kendte & & han & & & & & & & \\
\hline & & fordi & han & & & kendte & ham & & & \\
\hline fordi & & & & & & & & & & \\
\hline ham & kendte & & han & & & & & & & \\
\hline
\end{tabular}

Forkortelser: $y=y$ tringsadverbial, $R=$ syntaktisk rolleled. $X \backslash Y$ angiver at $X$ forudsatter til hojre, og $X / Y$ angiver at $Y$ forudsatter til venstre.

Der er her den ekstra formelle restriktion at nogle led kun kan optræde hvis et naboled er til stede, markeret med en brøkstreg således at det led der forudsætter det andet, er under brøkstregen, mens det led der er forudsat, står over brøkstregen, enten til højre eller til venstre; underordningskonjunktioner, k, kræver at der kommer et subjekt, s, umiddelbart efter: $\mathrm{k} \backslash \mathrm{s}$.

Denne notation indgår i formelle kategorielle grammatikker, som, i modsætning til de generative, beskriver de syntaktiske relationer i sætningen gennem kategorisering af de leksikalske størrelser (Steedman 1996). Ordet altid kan både høre til kategorien ytringsadverbial (/y), som defineres som det der sammen med et finit verbal til venstre udgør et finit verbal, og til kategorien udsigelsesadverbial (a\), som defineres som det der sammen med et verbum med neutral realitetsstatus (V, enten finit i ledsætninger, eller infinit i helsætninger) til højre udgør et verbum med neutral realitetsstatus (Togeby 2003: 98ff).

Man kan se at altid står på /y-pladsen i helsætningen og på a \-pladsen i ledsætningen. Det er en notation for at ordet har forskellig funktion og mening $\mathrm{i}$ de to eksempler. Man kan også bemærke at sætninger med underordningskonjunktion og ledsætningsordstilling ikke kan udnytte pladserne F, v og y. Er sætningens første ord fordi, som står på k-plad- 
sen (hvis der er et subjekt umiddelbart derefter), kan adverbialet ikke udnytte y-pladsen eftersom lille v-pladsen ikke er udfyldt med et finit verbum. Store V-pladsen kan kun fyldes med infinitte verber i helsætninger, men skal fyldes med både finitte og infitte verber i ledsætninger. Dermed markeres det at finitte verber i ledsætningsordstilling ikke har selvstændig sandhedsværdi. Hvis man efter ytringen af sætninger spørger til sandhedsværdien af ytringen, kan man kun spørge til verber der står på lille v-pladsen, ikke til dem der står på store V-pladsen.

\section{A: - Hun sà at han kom.}

B: - Gjorde bun?,

men ikke:

B: - Gjorde han?

Ledsætningsordstilling er således efter den danske skriftsprogsnorm et formelement med meningen 'udeklareret sandhedsværdi', dvs. med konceptuel mening, men uden propositionel mening. I talesproget har ledsætningsordstilling ikke samme tydelige mening især på grund af den hyppige brug med dækket direkte tale hvor ledsætninger har helsætningsordstilling: Hun sagde at ham kendte bun.

Der findes nemlig sætninger der er led i andre sætninger, men som har ordstilling som i helsætninger: Og så sagde Dirch at ham kendte han, for det var hans morbror. Man kan se at kendte står på v-pladsen, og derfor har selvstændig propositionel mening med sandhedsværdi. Men det er netop det der er meningen med det som i litteraturen kaldes dækket direkte tale; her udsiges sætningen både af den der ytrer hele sætningen, og af den der ytrer den refererede sætning, dvs. både af mig og af Dirch Passer (Togeby 2014: 194ff). Grammatikken forklarer meningen med helsætningsordstilling i ledsætninger.

\section{Notationssystemets kvalitet}

Når man skal sammenligne flere videnskabelige teorier og beskrivelser af det samme genstandsområde, fx af ledsætningsordstillingen i det danske sprog, kan man gå ud fra Hjelmslevs såkaldte empiriprincip: 
Beskrivelsen skal være modsigelsesfri, udtømmende og den simplest mulige. Kravet om modsigelsesfrihed er overordnet kravet om udtømmende beskrivelse. Kravet om udtømmende beskrivelse er overordnet kravet om simpelhed. Vi vover at benævne dette princip empiriprincippet. (Hjelmslev 1966: 12).

Den generative grammatik sikrer, i og med den er formaliseret, at den også er modsigelsesfri. Hvis regelsystemet ikke er konsistent, vil det ikke kun generere acceptable sætninger. Det kan man ikke være sikker på gælder de funktionelle grammatikker, hvor en sætning beskrives ved flere forskellige notationer og grafer, som man ikke kan være sikker på er forenelige. Eventuelle modsigelser kamufleres af forskellige beskrivelsesapparater.

Om beskrivelserne er udtømmende, kan man ikke afgøre så længe forskellige beskrivelser afgrænser genstanden for deres beskrivelser på forskellig måde og definerer centrale begreber som grammatiske regel, acceptabilitet og type og variant forskelligt (herom senere). Og om den ene beskrivelse er simplere end den anden, kan være meget svært at afgøre, for forskellene kan enten skyldes at metasprog, notationssystemer og grafer ikke er hensigtsmæssige, at den ene ikke beskriver præcis det samme som den anden, eller at der $\mathrm{i}$ en teori er gjort unødvendige teoretiske antagelser. Det er kun det sidste man - med Hjelmslev - kan opfatte som egentlig simpelhed.

De umiddelbart meget iøjnefaldende forskelle på de formelle og funktionelle grammatikere, nemlig metasprog, terminologi, notationsform og grafer, synes i virkeligheden ikke at være reelle forskelle. Det samme udsagn om strukturen i sætningernes form og formens funktion kan udtrykkes i begge notationsformer. Grammatikere fra de forskellige skoler kan derfor godt arbejde sammen om detaljer i den grammatiske beskrivelse, men det kræver et stort arbejde at oversætte et teoretisk udsagn fra den ene notationsform til den anden, og det er ikke klart for alle om de er enige eller uenige om en beskrivelse. Men alt $i$ alt er det kun formaliserede beskrivelsesapparater som den generative grammatiks der kan sikre modsigelsesfrihed. 


\section{METODE OG FALSIFIKATION}

På området for falsifikation er forholdene anderledes. Formelle grammatikere benytter især acceptabilitetstests, mens funktionelle grammatikere på grundlag af reglerne skal kunne redegøre for meningen med enhver faktisk forekommende sætningskonstruktion. Det som de generative grammatikere opfatter som to parametriske varianter af den samme principielle konstruktion, opfatter funktionelle grammatikere som to forskellige konstruktioner med forskellig mening. Der er således forskel på den metode grammatikerne bruger til at finde og analysere data, og til at falsificere (og dermed indirekte verificere eller sandsynliggøre) deres teorier og analyser.

På lyd- og bogstavsniveauet accepterer begge skoler en metode der viser om forskelle (i formen) gør en forskel (i indholdet) (jf. Batesons definition på information som de forskelle der gør en forskel (1970)): Hvis man udskifter et $s$ med et $l$ foran et $o$ eller $y$, skifter ordet betydning: so - lo, sy - ly, og man kan derved se at $s$ og $l$ er bogstaver (og fonemer) på dansk. Denne test er det der i den danske tradition hedder kommutationsprøven: Forskelle i form giver forskelle i funktion og indhold når man opfatter og forstår sproget, og forskelle $\mathrm{i}$ tanke eller indhold giver forskelle i form når man producerer sprog. Om dette er formelle og funktionelle grammatikere enige, omend de ser det fra hver sin side.

Formerne kan dog have varianter, fx kan man på skrift kende forskel på lille $s$ og stort $S$ og antika-s og kursiv-s, og derudover $s$ i forskellige skriftsnit, fx i Verdana og Times new Roman:

\section{S S og s S $S$}

Disse forskelle gør ingen forskel og er derfor varianter af de samme typer. Eksemplerne er forskellige grafer der alle opfattes som det samme grafem. I sprogvidenskaben skelner man således mellem typer, grafemer, og eksemplarer, grafer, som kan være grafemvarianter (allografer) af det samme grafem. Typerne er dem der skal beskrives i grammatikken, og varianterne skal der ses bort fra i grammatikken; varianterne, allofonerne og allograferne, kan dog så tages op som typerne $\mathrm{i}$ andre discipliner, fx sociolingvistik og layout. Eksemplarerne er empiriske 
data, mens typerne er normerede sociale kendsgerninger og dermed en del af teorien. Det er nu således at der både er typer og varianter på alle fire sproglige niveauer.

På morfem- og ordniveauet skal den samme udskiftning i formen give den samme forskel $\mathrm{i}$ indholdet: hun spis-er - bun spis-te, bun ramm-er bun ram-te. Deraf ser man at -er og -te er morfemer der betyder hhv. 'nutid' og 'fortid'. Men man ser også at nogle forskelle ikke gør en forskel, for også - $r$ kan betyde 'nutid': det ske-r - det ske-te. Indholdet 'nutid' kan således udtrykkes ved to forskellige former: - er og -r. Og de to morfemvarianter ram- og ramm- hører til samme type selv om de er forskellige kæder af grafemer. Det er forskelle i den fonetiske kombinatorik (om der står et $e$ - i ordstammen eller ej) der gør at 'nutid' kan have to forskellige former. På dette niveau er skolerne enige om at varianterne har samme betydning. Men varianter kan også afhænge af det overliggende niveau, fx når ordene udsagnsord og verbum har samme betydning, men forskellig stilvalør, som hører til niveauer over ordlaget. Er det så præcis samme betydning?

På sætningsniveauet, som er grammatikernes hjemmebane, er der hos formelle og funktionelle grammatikere forskellige procedurer til at finde sætningstyperne blandt sætningsvarianterne. Det kriterium som især er brugt i den generative grammatik, er acceptabilitetstesten. Den går ud på at sprogbrugere skal bedømme om en given form udgør en (grammatisk) acceptabel dansk sætning:

\section{a. Voksne brune bjorne sover lange. \\ b. Lange bjorne brune sover voksne. \\ c. Farvelose gronne ideer sover vildt}

Sætning a. er fuldt acceptabel, b. er helt uacceptabel, mens c. (som er Chomskys eksempel) er grammatisk acceptabel, men semantisk uacceptabel. Her betragtes sætninger altså som en enhed der enten følger normeringen i samfundet (hvad funktionalisterne lægger vægt på), eller som kan produceres af den menneskelige hjerne med dens biologiske ydeevne (hvad generativisterne hævder), eller som kan genereres af en formel grammatik der (i princippet) kan køre på en computer (hvad der i praksis er generativisternes metode, for de undersøger ikke hjerneproces- 
serne). Grammatiske fejl opfattes som uautoriserede varianter på det underliggende niveau, fx r-drop Det genere ham - Det generer ham, eller på det overliggende niveau, $\mathrm{fx}$ refleksive pronominer: Han tog hans hat og gike hans vej- Han tog sin hat og gik sin vej.

Et andet kriterium er om to sætninger betyder det samme, dvs. har den samme sandhedsværdi. Et kendt eksempel (også fra den generative grammatik) er aktive og passive sætninger som opfattes som sætningsvarianter af hinanden. Hun skriver ikke brevet om $=$ Brevet skrives ik.ke om af hende $=$ Brevet bliver ikke skerevet om af hende. Her opfattes en sætning som en logisk enhed der har en sandhedsværdi, dvs. om indholdet korresponderer med forholdene i verden som den er et udsagn om. De tre sætninger (transformationer): den aktive sætning, sætningen med $s$-passiv og sætningen med blive-passiv, opfattes af generativisterne som sætningsvarianter fordi de har den samme dybdestruktur, en struktur som er det der definerer meningen. Her opfatter funktionalisterne det netop som deres opgave at beskrive at sætningerne faktisk har forskellig mening, og at forklare at de forskellige meninger er systematisk relateret til de formelle forskelle.

Et tredje kriterium er om en given sætning faktisk er blevet produceret og faktisk forstået af sprogbrugere i en given sammenhæng. Det er den filologiske metode hvor man samler eksempler og (i princippet) analyserer alle de relevante eksempler for hvad de betyder. Man kan også samle dem i store korpusser og sammenfatte deres betydninger $\mathrm{i}$ ordbøger og grammatikker som er mere nuancerede end de formelle, men som ikke kan garantere konsistens.

Acceptabilitetstesten er i sig selv ikke tilstrækkelig som metode til at sandsynliggøre grammatisk struktur. Det skal her vises ved to eksempler. Verbet tanke kræver af sit objekt at det hører til meningstypen en tanke, fx i form af et sætningsudsagn: Hun tankte at han ikkee kom. Men når man så støder på en filmtitel der hedder: Manden der tankte ting, må man tolke sætningen metaforisk og forstå at han havde den evne at når han, som Gud, tænkte på en ting, så fik denne ting også eksistens i verden. Det er ganske vist, så vidt vi ved, usandt, men sætningen er blevet brugt, og den giver mening selv om den overtræder eksisterende regler - lige som Farvelose gronne ideer sover vildt. Forklaringen er at verbet tanke, når det tager en at-sætning som objekt, har den betydning 
af tænkeren skaber tanken (at-sætningen). Det er altså meningen med den syntaktisk definerede konstruktion antageverbum + objekt (Togeby 2003: \$214).

Generativisterne beskriver således Manden der tankte ting som grammatisk acceptabel, men semantisk uacceptabel, og de giver derfor ikke nogen yderligere forklaring. Funktionalisterne derimod har til opgave at forklare hvad denne faktisk forekommende sætning betyder, og hvordan meningen er en konsekvens af de leksikalsk-semantiske regler - som er skitseret ovenfor. Generativisterne opretholder total adskillelse af de formelt beskrivbare syntaktiske regler og de ikke umiddelbart synlige semantiske regler, mens funktionalisterne opfatter syntaks og semantik som et sammenhændende regelsystem som beskriver hvorledes form får mening. Begrebet grammatisk metafor er derfor en vigtig del af beskrivelsen.

De to omtalte passivformer: $s$-passiv og blive-passiv, er ikke nødvendigvis formvarianter af samme mening, hvad man kan se af følgende kommutationsprøve, som er skarpere end simpel acceptabilitet: Det skal vises - Det skal blive vist. Den første er en ordre, det andet et løfte. Det er altså ikke to varianter af den samme sætningskonstruktion, men to forskellige konstruktioner som netop er udviklet på dansk for at man kan udtrykke denne betydningsforskel.

Der er også typer og varianter på tekstens og handlingens niveau, men da grammatikere har afgrænset deres genstandsområde ved sætningsgrænsen, vil disse varianter kun blive beskrevet i grammatikken for så vidt de kommer til udtryk i en enkelt sætning, fx: Ham kender jeg = Jeg kender ham og Vil du (gerne) komme her? \# Vil du (straks) komme her!

\section{ERKENDELSESINTERESSER}

For (især strukturalistiske) grammatikere er det sprogets regelsystem der står i centrum for interessen, ikke anvendelsen af reglerne. Sprogets system kalder de formelle grammatikere for competence (i modsætning til performance), mens funktionalisterne kalder det la langue (efter Saussure), eller sprogbygningen (efter Hjelmslev). Alene dette valg af terminologi åbenbarer forskellige erkendelsesinteresser. 
Generativisterne opfatter sprogets indre struktur som i grunden biologisk; grammatikken beskriver ikke den ydre struktur i faktisk ytrede sætninger, men den ubevidste viden og evne som ethvert menneskeligt individ nødvendigvis må have for at kunne bruge sproget. Af disse færdigheder er nogle medfødte og andre tillærte $\mathrm{i}$ individets barndom, men de er $\mathrm{i}$ alle tilfælde biologiske og ikke socialt eller historisk bestemt. Det er så den universelle medfødte indre grammatik generativisterne ønsker at beskrive.

Funktionalisterne interesserer sig især for de strukturer som i et givet sprog er fælles for sprogbrugerne i sprogsamfundet, og mere for de regler der er indlærte, dvs. styret af sociale normer, end for de regler der er medfødte. Funktionalister må selvfølgelig også antage at sprogevnen er medfødt (siden ingen andre dyr har sprog af samme kompleksitet som det menneskelige sprog), men interessen gælder hvilken funktion sprogets regler har for at sproglig kommunikation virker i et historisk betinget socialt fællesskab, ikke for hvad det biologiske grundlag er for at vi har den.

Et af argumenterne for den medfødte sprogevne er det generativisterne kalder poverty of stimulus (Chomsky 1988): det faktum at børn kan lære regler for strukturen i korrekte og acceptable sætninger selv om det de hører, er yderst fattigt og ofte med ufuldendte og ukorrekte sætninger. Dette argument er dog selv baseret på en temmelig fattig (behavioristisk?) opfattelse af indlæring, hvor der kun ses på barnets tilegnelse af former, men ikke på at barnet bruger formerne som et middel til i det hele taget at skabe mening, og til at indgå i det sociale fællesskab. Det er det der driver indlæringen, ikke en betingning, dvs. ydre belønning ved reaktion på stimuli, det er det menneskelige behov for mening. Mening kan man få selv om formen er korrumperet. Fx kan man godt få mening med Farvelose ideer sover vildt, nemlig som en metafor for noget som sproget ikke har ord for. Stimuli er altså ikke fattige, men altid rige for den der søger mening.

For at sandsynliggøre tesen om den medfødte competence må man, ironisk nok, nødvendigvis undersøge performance, dvs. hvordan brugen af sprogets strukturer overhovedet kan foregå i kommunikation. Og her kan alle parter blive enige om at sproglig performance forudsætter evnen til at udføre to typer af mentale processer, nemlig generative og rekursive processer. Om der er andre universalier i den indre grammatik, fx C-command, er derimod tvivlsomt og kræver en større undersøgelse. 
Men generative og rekursive processer forudsættes også for mange andre motoriske processer og målrationelle handlinger, $f x$ at gå $\mathrm{og}$ at spille bold; de er ikke særlige for beherskelsen af sproglige regler. Rekursivitet er ikke et særligt sprogligt fænomen selv om det er en forudsætning for at sprog kan have de strukturer de har. Men hvis der findes særlige grammatiske gener hos mennesket, har generativisterne et problem med at forklare hvorledes sprogspecifikke egenskaber kan være blevet selekteret som de mest "fitte" når der ikke var noget sprog de skulle fungere $\mathrm{i}$.

Funktionalisterne er mere interesseret $i$ at undersøge hvordan sprogevnen igennem evolutionen og historien kunne udvikle sig fra den tid da menneskene skilte sig ud fra aberne (hvis biologi jo også fuldt ud behersker generative og rekursive processer). Hvad er det særligt menneskelige som gør at vi har et sprog som aberne ikke har?

Tomasello (2014) foreslår at det der er det særligt menneskelige, og som er forudsætningen for sprogevnen, ikke er grammatik, men socialitet: evnen til fælles opmærksomhed, intentionsaflæsning, fælles mål, tillid, kollektiv intentionalitet og akkumulering af kultur gennem opdragelse af afkommet. Evolutionshistorisk kan det så antages at have fundet sted for 400.000 år siden hvor mennesket havde den evolutionære fordel at de bl.a. på grundlag af sprog kunne samarbejde på måder andre aber ikke kunne, og derved overleve i kampen for tilværelsen.

Det skal ikke her diskuteres om sprogteorier på denne måde er gode argumenter i forbindelse med hhv. biologi og evolution. Men man kan lægge mærke til at der ikke på forhånd er nogen modstrid mellem at undersøge det biologiske grundlag for sprog og den evolutionære udvikling af sprog. Det er derfor man godt kan betragte de to skolers grammatiske teorier som forsøg på at bore en tunnel fra hver sin side og håbe at man mødes på midten. Men det ser ud som om de formelle og de funktionelle grammatikere, på grund af deres forskellige erkendelsesinteresser, både lægger snittet mellem meningsfulde typer og forskelsløse varianter forskelligt og derpå drager forskellige konklusioner af de samme data for hvad der er universelt, og hvad der er historisk i sprog. 
Det fortryder dig

Som et eksempel på hvorledes erkendelsesinteressen kommer til at styre den videnskabelige undersøgelse og beskrivelse af et emne, kan man tage verbet fortryde som det blev brugt i 1843. Der er i Søren Kierkegaards Forforerens Dagbog (1962) fire eksempler på det divalente verbum fortryde. De to af dem er konstrueret lige som argre således at sagen (den neutrale semantiske rolle, thetarollen tema, E-rollen) er grammatisk subjekt, og personen (experiencer, dativen, H-rollen) er grammatisk objekt :

Det argrer/fortryder mig at jeg besogte hende.

Mit besog hos hende argrer/fortryder mig.

De to andre er konstrueret lige som angre med personen som subjekt og sagen som objekt:

Jeg angrer/fortryder at jeg besogte hende.

jeg angrer/fortryder mit besog hos hende.

Begge konstruktioner var brugbare på Kierkegaards tid, mens konstruktionen med sagen som subjekt er helt ubrugelig i dag. Der er altså i midten af 1800-tallet sket en sproghistorisk udvikling der er parallel til den udvikling der (antagelig i 1400-tallet) er sket med verbet dromme, som kunne konstrueres med personen i oblik kasus: Dromte mig en drom i nat, mens vi i dag kun kan sige Jeg dromte en drom $i$ nat.

Gunnar Hrafnbjargarson (2004) har fremsat den teori at disse sproghistoriske udviklinger for konstruktioner om personers bevidsthedsreaktioner i de nordiske sprog og engelsk kan beskrives således at der først var en sprogtilstand med konstruktioner med subjekt i dativ og objekt i nominativ, 1: mig $_{\text {dat }}$ dromte en drom nom, så konstruktioner med dat og akkusativ, 2: mig dat dromte en drom ${ }_{a k k,}$, og til sidst konstruktioner med nominativ og akkusativ, 3: jeg nom $_{\text {no }}$ dromte en dromake.

Pladsen tillader ikke diskussion af teorien om dativiske subjekter, og det er da også kun overgangen fra sprogtrin 2 til 3 der er relevante for fortryde-eksemplerne. Men det er væsentligt at den generative grammatik opfatter syntaksen (med vægt på beskrivelsen af konstruktionernes 
form) som et autonomt maskineri der, fordi det er biologisk funderet, kører uafhængigt af formernes mening og dens funktion i samfundet. Om overgangen fra 2. til 3. konkluderer Hrafnbjargarson følgende:

I have argued that the change cannot have been due to a structural reanalysis because there have been no changes in the semantics from Old English to Modern English. Rather there has been a reanalysis in the case assignment of verbs in DAT-NOM constructions. To begin with, these verbs lost their ability to assign nominative to the object and later, the same verbs lost the ability to assign dative to the subject. (Hrafnbjargarson 2004: 75)

Den afgørende præmis i denne argumentation er at de tre typer af konstruktioner har den samme semantik, altså at Dromte mig en drom $i$ nat og Jeg dromte en drom i nat har samme betydning.

Denne påstand kan imidlertid betvivles, ikke på grundlag af acceptabilitetstests, men med en filologisk analyse. De indianere der laver drømmefangere der ligner en ketsjer med hul i midten, mener antagelig at trådnettet vil fange de gode drømme mens de onde drømme passerer gennem hullet når man hænger drømmefangeren over sin seng. Det kan således opfattes som en del af meningen med Dromte mig en drom $i$ nat at drømmene er derude og kommer ind i bevidstheden og ændrer den. Det er på denne måde vi også opfatter meningen Det argrer mig at det skal vare sådan; forholdene er ude i verden, og personen reagerer med tanker og følelser på det.

Den der derimod siger: Jeg dromte en drom $i$ nat, må forestille sig at drømmen er noget som er privat for personen, nemlig resultatet af processer $\mathrm{i}$ hjernen, på samme måde som Jeg angrer at jeg gjorde det opfattes som en bevidsthedsproces som ikke forårsages af noget ydre, men som kun handler om noget indre.

Det er nu påstanden her at Kierkegaard ikke vakler mellem to forskellige sætningsstrukturer med samme mening, men at han mener to forskellige ting med dem: Det fortryder mig og Jeg fortryder det. Forførerens Dagbog er dagbogsoptegnelser og breve skrevet af Johannes om hvilke tanker han gør sig i den periode hvor han planlægger og gennemfører at forføre Cordelia, som er den brevene og nogle af optegnelserne er adresseret til. 
Det faldt mig ind, maaskee hører hun til herude paa Landet, maaskee har Familien Sommerværelser. Jeg var allerede ifærd med at fortryde mit Besøg, af Frygt for, at hun skulde vende om og jeg tabe hende af Sigte, ja dette, at hun blev synlig paa Broens yderste Spidse var ligesom et Tegn paa, at hun forsvandt for mig - da hun viste sig nærved. (Kierkegaard 1962: 309)

Ikke fortryder jeg hvad Tid Cordelia koster mig, skjøndt hun koster mig megen. (Kierkegaard 1962: 352)

- Altsaa i Stormgaden boer De. De neier koldt og flygtigt for mig. Har jeg fortjent det, jeg der hjalp Dem ud af den hele Ubehagelighed? Det fortryder Dem, De vender tilbage, takker mig for min Artighed, rækker mig Deres Haand - hvorfor blegner De? Er min Stemme ikke uforandret, min Holdning den samme, mit Øie ligesaa stille og roligt? (Kierkegaard 1962: 296)

Hun er stolt og har tillige ingen egentlig Forestilling om det Erotiske. Medens hun nu vel i aandelig Henseende til en vis Grad bøier sig for mig, saa lod det sig tænke, at hun, naar det Erotiske begynder at gjøre sig gjeldende, kunde faae i Sinde at vende sin Stolthed mod mig. Efter Alt hvad jeg kan iagttage, er hun raadvild om Qvindens egentlige Betydning. Derfor var det let at reise hendes Stolthed mod Edvard. Denne Stolthed var imidlertid aldeles excentrisk, fordi hun ingen Forestilling havde om Elskov. Faaer hun denne, saa faaer hun sin sande Stolthed; men en Rest af hiin excentriske kunde let slaae sig til. Det var da tænkeligt, at hun vilde vende sig mod mig. Skjøndt det ikke vil fortryde hende, at have givet sit Samtykke til Forlovelsen, saa vil hun dog let see, at jeg fik det for temmelig godt Kjøb; hun vil see, at Begyndelsen fra hendes Side ikke er rigtigt gjort. Gaaer dette op for hende, saa vil hun vove at byde mig Spidsen. Saaledes skal det være. Da faaer jeg mig forvisset om, hvor dybt hun er bevæget (Kierkegaard 1962: 353)

Det er - i Johannes' sprog - Johannes der fortryder på samme måde som han angrer, mens det er Cordelia som det fortryder på samme måde som det ærgrer hende. Det er næppe tilfældigt. Det viser at Johannes opfatter sig selv som bevidst og viljestyret, mens han opfatter Cordelia som ubevidst og impulsstyret. Fortryde betyder altså noget forskelligt efter hvordan det er konstrueret. 
I den sproghistoriske udvikling har en række verber på forskellige tidspunkter gennemgået den samme udvikling hvorunder den oblikke kasus (oprindelig dativ) er blevet nominativ, og det andet rolleled er en at-sætning der bliver direkte eller middelbart objekt (Togeby 2015).

1. drømte mig at - jeg drømte at

2. det mangler mig - jeg mangler det

3. det fortryder mig at - jeg fortryder at

4. det synes mig at - jeg synes at

5. det lykkes mig at - jeg lykkes med at

Mens 1. er sket for fem-seks hundrede år siden, er 2. og 3. sket for et par hundrede år siden, 4. for 100 år siden, og 5. er ved at ske lige nu; bedsteforældre siger det bkkees mig, og børnebørn siger jeg blkkes med. Det er ikke blot en omanalyse af kasustilskrivningen, men en ændring $\mathrm{i}$ sprogbrugernes verdensopfattelse. Børnene tror mere på at de er deres egen lykkes smed, end bedsteforældrene, som føler sig i tilfældets vold. Valget af konstruktion er blot et symptom på dette. Den sproghistoriske udvikling af konstruktioner med verber om bevidste reaktioner, som er gået fra at have sagen $i$ nominativ og personen $i$ dativ til at have personen i nominativ og sagen $i$ akkusativ, synes at afspejle en generel udvikling til mere individualisme, en udvikling der er kommet til udtryk gennem skiftet i konstruktionstype på forskellige semantiske områder gennem 800 år.

\section{KONKLUSION}

Ud fra en analyse af udvalgte formelle og funktionelle grammatikeres metasprog og notationssystemer, specielt dem til beskrivelse af ledsætningsordstilling $\mathrm{i}$ dansk, kan det konkluderes at generative konstituenttræer med flytninger angivet med pile er ækvivalente med topologiske skemaer med tomme pladser, men at træerne er mere konsistente end skemaerne, der nemlig må angive den detaljerede konstituentstruktur og dependensstrukturen med andre notationssystemer end skemaerne. Derved er modsigelsesfriheden korrumperet. De to grammatikskolers beskrivelser kan altså sammenlignes, og ved afvigende beskrivelser 
kan man i princippet diskutere hvilken beskrivelse der er bedst. Men det kræver meget energikrævende oversættelse, som der ikke findes så mange eksempler på i litteraturen. Forskellen på notationssystemerne kan også hænge sammen med om de opfattes som kun deskriptive, eller også eksplanative, hvad træerne siges at være, eller også heuristiske, hvad en udformning af skemaerne siges at være.

Skolerne anvender for det meste forskellige falsifikationsprocedurer: Den generative skole har betonet acceptabilitetstesten i sammenhæng med forestillingen om at competence er et biologisk fænomen lokaliseret i den enkelte sprogbruger, mens (visse) funktionalistister fremhæver den historisk-filologiske metode, hvorefter forekommende eksemplers mening analyseres i deres helhed, dvs. både syntaktisk, semantisk og pragmatisk og i deres historiske situerethed. I denne sammenhæng spiller stil, sprogfejl og metaforer en rolle som kun kan forklares hvis man opfatter la langue som et samfundsmæssigt fænomen (som fungerer på grundlag af individernes biologiske evner). Denne forskel i om perspektivet er biologisk eller samfundsmæssigt, gør at skolerne kan sætte grænsen mellem type og variant forskelligt - med forskellige beskrivelser som resultat. Skolerne undersøger ganske simpelt ikke helt de samme fænomener.

Som erkendelsesinteresse har den generative grammatik først og fremmest at finde den universelle grammatik som udgør det biologiske grundlag for sprogudøvelsen (som i det mindste omfatter generativitet og rekursivitet), mens den funktionelle grammatik søger at finde hvad der i evolutionen og historien har adskilt mennesket fra menneskeaberne (nemlig at sprog hviler på socialitet, tillid og kultur). Til sidst er det vist hvorledes erkendelsesinteressen i hhv. biologi og socialitet har givet forskellige resultater i beskrivelsen af konstruktionsændringen i midten af 1800-tallet fra Det fortryder mig til Jeg fortryder det på dansk.

Dette eksempel illustrerer hvorledes erkendelsesinteressen påvirker forskningsprocessen således at generativisterne i søgningen efter den universelle medfødte grammatik opfatter to måder at konstruere det samme verbum på som sætningsvarianter der har samme mening, men som er styret af mekanikken i en autonom biologisk funderet syntaks. I denne er, efter den anvendte optimalitetsteori, reglerne for opbygningen af konstruktionstyper ordnet i forskellig rækkefølge på forskel- 
lige sprog uafhængigt af meningen (Hrafnbjargarson 2004), hvad der forklarer hvorfor islandsk og dansk har forskellig grammatik for sætninger med "samme" mening, selv om sprogene har samme historiske udgangspunkt.

En funktionel grammatiker søger derimod efter hvilke meningsforskelle der er mellem to forskellige måder at konstruere de samme verber på, for at belyse hvorledes sproget gennem (evolutionen og) historien har været middel for sprogbrugerne til bedre overlevelse i de skiftende omgivelser, i dette tilfælde til at differentiere opfattelsen af mentale reaktioner på ydre omstændigheder så de svarer til virkeligheden. Skiftet $\mathrm{i}$ konstruktion følger en skiftende verdensopfattelse.

Hovedkonklusionen må være at de lingvistiske skoler med fordel kan arbejde sammen og på metodisk vis prøve at falsificere hinandens resultater sådan som videnskab bør bedrives.

Ole Togeby

Institut for Kommunikation og Kultur

Aarhus Universitet

norot@cc.au.dk 


\section{LITTERATUR}

Bateson, G. 1970. Form, substance and difference. G. Bateson 1972, Steps to an ecology of mind. London: Paladin

Bjerre, T. m.fl. 2008. Points of convergence between functional and formal approaches to syntactic analysis. Working papers in Scandinavian syntax 82. 131-166.

Chomsky, N. 1988. Language and problems of knowledge. Cambridge Mass.: MIT Press.

Christensen, K. 2009. Hjernebark og syntaktiske træer. Tidsskrift for Sprogforskning 7(1). DOI: $10.7146 /$ tfs.v7i1.2733.

Diderichsen, P. (1946) 1957. Elementar dansk grammatik. København: Gyldendal.

Dik, S. 1989. The theory of functional grammar. Dordrecht: Foris Publications.

Halliday, M. 1994. An introduction to functional grammar. London: Edward Arnold. Hansen, E. \& L. Heltoft. 2011. Grammatik over det danske sprog I-III. København: Det Danske Sprog- og Litteraturselskab.

Hjelmslev, L. (1943) 1966. Omkring sprogteoriens grundlaggelse. København: Akademisk Forlag

Hrafnbjargarson, G. 2004. Oblique subjects and stylistic fronting in the bistory of scandinavian and english. The role of IP-spec. Ph.d.-afhandling. Århus Universitet. DOI: 10.7282/T3DV1HRW.

Kierkegaard, S. 1962. Samlede varker bind 2, Enten Eller: 8. Forforerens Dagbog. København: Gyldendal.

Platzack, C. 1998. Svenskans inre grammatik - det minimalistiska programmet. En introduktion till modern generativ grammatik. Lund: Studentlitteratur.

Steedman, M. 1996. A very short introduction to CCG*. www.inf.ed.ac.uk. (25. maj, 2017).

Togeby, O. 2003. Fungerer denne satning? Funktionel dansk sproglare. København: Gads Forlag.

Togeby, O. 2014. Bland blot genrerne - ikeke tekstarterne. København: Samfundslitteratur.

Togeby, O. 2015. En drøm om ideologisk valens. D. Duncker m.fl. (red), Rette ord. Festskrift til Sabine Kirchmeier-Andersen $i$ anledning af 60-ärsdagen. Dansk Sprognævns skrifter 46: Dansk Sprognævn.

Tomasello, M. 2014. A natural history of human thinking. Cambridge, MA: Harvard University Press. DOI: 10.4159/9780674726369.

Watzlawick, P., J. Beavin \& D. Jackson. 1968. Pragmatics of human vommunication. A study of interactional patterns, pathologies and paradoxes. London: Faber and Faber. 